ORIGINAL ARTICLE

\title{
CDKL5/STK9 is mutated in Rett syndrome variant with infantile spasms
}

\author{
E Scala, F Ariani, F Mari, R Caselli, C Pescucci, I Longo, I Meloni, D Giachino, M Bruttini, G Hayek, \\ M Zappella, A Renieri
}

J Med Genet 2005;42:103-107. doi: 10.1136/jmg.2004.026237

See end of article for authors' affiliations

..................

Correspondence to: Dr A Renieri, Associate Professor, Medical Genetics, University of Siena, Policlinico Le Scotte, viale Bracci 2, 53100, Siena, Italy; renieri@ unisi.it

Received 7 August 2004 Revised 4 October 2004 Accepted 5 October 2004

\begin{abstract}
Background: Rett syndrome is a severe neurodevelopmental disorder, almost exclusively affecting females and characterised by a wide spectrum of clinical manifestations. Both the classic form and preserved speech variant of Rett syndrome are due to mutations in the MECP2 gene. Several other variants of Rett syndrome have been described. In 1985, Hanefeld described a variant with the early appearance of convulsions. In this variant, the normal perinatal period is soon followed by the appearance of seizures, usually infantile spasms. We have observed two patients with signs of Rett syndrome showing acquired microcephaly and stereotypic midline hand movements. The disease started with generalised convulsions and myoclonic fits at 1.5 months in the first patient and with spasms at 10 days in the other, suggesting a diagnosis of the Hanefeld variant. In these patients, MECP2 point mutations and gross rearrangements were excluded by denaturing high performance liquid chromatography and real time quantitative PCR. The ARX and CDKL5 genes have been associated with West syndrome (infantile spasms, hypsarrhythmia, and mental retardation).

Methods: Based on the clinical overlap between the Hanefeld variant and West syndrome, we analysed $A R X$ and $C D K L 5$ in the two girls.

Results: We found frameshift deletions in CDKL5 in both patients; one in exon 5 (c.163_166delGAAA) and the other in exon 18 (c.2635_2636delCT). CDKL5 was then analysed in 19 classic Rett and 15 preserved speech variant patients, all MECP2 negative, but no mutations were found.

Conclusion: Our results show that CDKL5 is responsible for a rare variant of Rett syndrome characterised by early development of convulsions, usually of the spasm type.
\end{abstract}

$\mathrm{R}$ ett syndrome (RTT; MIM\# 312750) is a neurodevelopmental disorder characterised by a wide spectrum of clinical manifestations. In the classic form, after a period of normal development, patients show growth retardation and regression of speech, along with purposeful hand movements and appearance of stereotyped hand movements RTT variants have been described, including the preserved speech variant (PSV), characterised by the recovery of some degree of speech; the congenital variant (recognised from birth); the "early seizure variant" (seizure onset before regression); and the "forme fruste", with a milder, incomplete clinical course (regression between 1 and 3 years). ${ }^{1-6}$ These variants present some symptoms of RTT, but show considerable variation in type and age of onset, severity of impairment, and clinical course. Among these, the "early seizure variant" was initially described by Hanefeld in 1985 who reported a girl with infantile spasms with hypsarrhythmia in her early development. ${ }^{3}$

Approximately $80 \%$ of patients with classic RTT have a mutation in the methyl CpG binding protein 2 gene (MECP2; OMIM \#300005). ${ }^{7-9}$ MECP2 mutations have also been identified in about $50 \%$ of PSV cases and in a lower percentage of other variants. ${ }^{8}{ }^{10-12}$ In the variant with early development of convulsion described by Hanefeld, MECP2 mutations have not been published. ${ }^{3}$

The Hanefeld variant of RTT presents a phenotypic overlap with West syndrome, also called infantile spasm syndrome, $X$ linked (ISSX). ISSX is characterised by the triad of infantile spasms, hypsarrhythmia, and severe to profound mental retardation. Some families with ISSX carry mutations in the aristaless related homeobox $(A R X)$ gene, which maps to Xp21.3-p22.1. ${ }^{13}$ ARX mutations cause several forms of epilepsy, including infantile spasms, myoclonic seizures, and peripheral dystonia, as well as syndromic and nonsyndromic $X$ linked mental retardation. ${ }^{13}{ }^{14}$ Recently, a second gene has been found to be involved in ISSX, the cyclin dependent kinase-like 5 gene (CDKL5/STK9; NM_003159). ${ }^{15}$ These authors characterised two unrelated female patients with an apparently balanced translocation, $46, X, t(X ; 7)(\mathrm{p} 22.3 ; \mathrm{p} 15)$ in one case and $46, X, t(X ; 6)$ $(\mathrm{p} 22.3 ; \mathrm{q} 14)$ in the other. The two patients presented a similar phenotype, comprised of severe early onset infantile spasms with hypsarrhythmia and profound global developmental arrest. In both patients, the $X$ chromosomal breakpoints disrupted CDKL5. As there is phenotypic overlap between the Hanefeld variant and ISSX, we tested both ARX and CDKL5 for mutations in the two RTT patients with early onset of convulsions. The analysis was subsequently extended to 19 classic RTT and 15 PSV cases.

\section{METHODS}

\section{Patients}

We investigated two patients, aged 9 and 8 years respectively, with early development of convulsions, who later developed many characteristics of RTT. They both fulfilled the criteria for the early seizure variant of RTT. ${ }^{516}$

We then investigated 19 classic RTT and 15 PSV patients. The girls with classic RTT were diagnosed according to the international criteria. ${ }^{17}$ The PSV girls fulfilled the criteria of Hagberg and Skjedal for RTT variants. ${ }^{5}$ In particular, the PSV

Abbreviations: DHPLC, denaturing high performance liquid chromatography; ISSX, infantile spasm syndrome, X linked; PSV preserved speech variant; RS, retinoschisis; RT, Rett syndrome 
cases show the same clinical features and stages of RTT in the first years of life, but they subsequently improve in fine motor ability and start to speak with an increasing number of words and phrases.

\section{Molecular analysis}

Blood samples were obtained after informed consent. DNA was extracted from peripheral blood using a QIAamp DNA blood kit (Qiagen). DNA samples were screened for mutations in $A R X$ and CDKL5 using transgenomic WAVE denaturing high performance liquid chromatography (DHPLC). The CDKL5 coding portion was entirely analysed using the primers and conditions given in table 1. PCR products resulting in abnormal DHPLC profiles were sequenced on both strands by use of PCR primers with fluorescent dye terminators on an ABI Prism 310 genetic analyser (PE Applied Biosystems, Foster City, CA, USA). PCR products of exon 5 and exon 18 were separated on $6 \%$ polyacrylamide gel to define exactly the deleted bases. Normal and mutant alleles were cut from the gel and sequenced individually. $\mathrm{X}$ inactivation studies were performed using the assay of Pegoraro et al. Intensity of silver stained bands was measured using the Diversity Database program (Biorad) and the values were corrected for preferential allele amplification. ${ }^{18}$ RNA isolation from lymphoblasts and cDNA synthesis were performed according to standard protocols. ${ }^{19}$ We used primers designed to form cDNA products spanning exons 4-6 (4RTf: 5'-GAAACA CATGAAATTGTGGCG-3'; 6RTr:5'-GTGAATAGCCTTGATTAG CTG-3') and 17-18 (17RTf: GAGAAGATCTCAGATCTGCAG; 18RTr: AGCTGGAGGGCTGGCCTG). RT-PCR products were separated by electrophoresis through a $6 \%$ polyacrylamide gel and silver stained.

\section{RESULTS}

We observed two patients with early development of convulsions who later showed characteristics of RTT. The phenotype of each case is described below.

\section{Patient 1}

This patient is a girl, now aged 9 years. Her pedigree is represented in fig lA (left). The mother had a normal pregnancy and delivery. The child was affected with slight cyanosis after birth. Birth weight was $3600 \mathrm{~g}$ and head circumference was $34 \mathrm{~cm}$ (50th centile). Generalised convulsions appeared at 1.5 months of age and were barely controlled by various antiepileptic drugs. In the following months she was examined in hospital, and myoclonic fits resembling infantile spasms were noted, although her EEG was not typical of hypsarrhythmia. Her developmental milestones were delayed and she was able to sit unaided at 1 year and to walk unaided at 6.5 years. She was examined again in hospital at the age of 2 years. MRI of the head, evaluations for aminoacidaemia, karyotype, search for Fragile $\mathrm{X}$ syndrome, methylation pattern for Angelman syndrome, and $U B E 3 A$ gene sequencing were all negative. The patient was initially examined in our unit at the age of 8.5 years. She was able to briefly hold an object in her hands, dropping it shortly afterwards. She brought her hands frequently to her mouth, or beat them together. She had stereotypic handwashing activities, reported as occurring since the age of 1 year. Her facial expression varied and she was able to interact at a pre-verbal level. She was able to utter one word and had occasional bruxism and hyperventilation. Her head circumference was 48.5 (<3rd centile). Scoliosis, kyphosis, cold extremities, and constipation were not present. The EEG showed sharp waves in the central and occipital regions.

Table 1 Primer sequences and conditions for PCR reaction and DHPLC analysis of CDKL5 amplicons

\begin{tabular}{|c|c|c|c|c|c|c|}
\hline \multirow[b]{2}{*}{ Exon } & \multirow[b]{2}{*}{ Forward primer } & \multirow[b]{2}{*}{ Reverse primer } & \multirow[b]{2}{*}{$\begin{array}{l}\text { Product } \\
\text { length (bp) }\end{array}$} & \multirow[b]{2}{*}{$\begin{array}{l}\text { PCR annealing } \\
\left.\text { temp ( }{ }^{\circ} \mathrm{C}\right)\end{array}$} & \multicolumn{2}{|c|}{ DHPLC analysis } \\
\hline & & & & & $\begin{array}{l}\text { Temp of } \\
\left.\text { elution ( }{ }^{\circ} \mathrm{C}\right)\end{array}$ & $\begin{array}{l}\text { Buffer } \\
(\%)\end{array}$ \\
\hline 2 & AGGTAAGATTGGTTACTAGAG & AATAACTAACTGTTCATTGCTC & 350 & 58 & $\begin{array}{l}55 \\
57\end{array}$ & $\begin{array}{l}57 \\
57\end{array}$ \\
\hline 3 & TGAGAAGCAATGTCAGTATAG & CCTGTACATGCCCACACGC & 201 & 58 & 55 & 53 \\
\hline 4 & CTGGCTTCTTGCTACTCTG & ТСССАСТТСТТССАСАСТС & 242 & 58 & 54 & 53 \\
\hline 5 & AGTGTTCTTGGAATTCTTTG & GGCAAATGTGCACATTGGC & 244 & 54 & 57 & 53 \\
\hline 6 & CTCTGTATTGGATGAATTATTC & TTCTTAAAGACAGTAACATGTG & 303 & 59 & $\begin{array}{l}54 \\
56\end{array}$ & $\begin{array}{l}55 \\
55\end{array}$ \\
\hline 7 & TITATCTTGACACTCCAGA & АСТССТCCAGCAATCAATT & 237 & 56 & 53 & 53 \\
\hline 8 & GCCCATCGGAGAACAGTCATTAC & GCAAATGACAATAGAATCAGCAG & 280 & 55 & $\begin{array}{l}56 \\
57\end{array}$ & $\begin{array}{l}54 \\
54\end{array}$ \\
\hline 9 & TTATTCACTTGTGTTCTGATGAT & CAAATACTGCAGTATTGATTCC & 410 & 54 & $\begin{array}{l}54 \\
56\end{array}$ & $\begin{array}{l}58 \\
58\end{array}$ \\
\hline 10 & TATGAATTTGACTGGGATTGG & CTATGGTCACATGTAGACAC & 275 & 59 & 57 & 54 \\
\hline 11 & TTGATATTCTGCAATGACTGTG & AGCCACCTCCTCCACCTAC & 333 & 62 & $\begin{array}{l}53 \\
55\end{array}$ & $\begin{array}{l}56 \\
56\end{array}$ \\
\hline $12 \_a$ & TTGTGTGTCAGCTATTGAGG & GGITCTGCTGAGATCTGCTG & 406 & 60 & $\begin{array}{l}56 \\
59\end{array}$ & $\begin{array}{l}60 \\
60\end{array}$ \\
\hline $12 \_b$ & CAACAACATACCACACCTTC & TTCTCGTGTCACTGTGTCTG & 422 & 60 & $\begin{array}{l}57 \\
60\end{array}$ & $\begin{array}{l}60 \\
60\end{array}$ \\
\hline $12 \_c$ & ACTCCAAGTCTGTGAGCAAC & AGATGGACCCTCATCACATC & 541 & 60 & 57 & 63 \\
\hline $13^{-}$ & GGTTATGGTCCTAGTTCTAC & CACTTCAACTTATTTGTGGG & 298 & 60 & $\begin{array}{l}57 \\
59\end{array}$ & $\begin{array}{l}55 \\
55\end{array}$ \\
\hline 14 & CAATAGAGTGAGACCCTGTC & CTGAGTCGGTGAAAGCAGTG & 279 & 65 & $\begin{array}{l}57 \\
60\end{array}$ & $\begin{array}{l}55 \\
55\end{array}$ \\
\hline 15 & AAAAGTCCATCAGTGACTTAC & CCTAGCAGGAGAAAGGACAC & 262 & 60 & 56 & 54 \\
\hline 16 & TATAGGAACCTAGTGTCATGC & CAACTTTGATTGCCAAGTGC & 293 & 59 & 53 & 57 \\
\hline 17 & CTTGGGTGTGGTTGCATATC & CTGTAACATTGAGAGGCTAAG & 296 & 60 & 59 & 55 \\
\hline 18 & CTTGCACATGCTTGCCCTTC & CACCCAGCTGTTCAGAGTAG & 418 & 62 & 61 & 58 \\
\hline 19 & ACTCTGGTCAATGGGATGTG & CATTCAGTAGTCTAGGGTCG & 249 & 60 & 59 & 53 \\
\hline 20 & TTGGCTTCAGCTGGTGTCTG & CATCTGCATTTCTACAGCTC & 345 & 61 & 61 & 58 \\
\hline 21 & CATTAGCCAGAGTGCACCTG & AGGAAAAACTCAACCTCAGCG & 290 & 60 & $\begin{array}{l}59 \\
63\end{array}$ & $\begin{array}{l}55 \\
54\end{array}$ \\
\hline
\end{tabular}


A

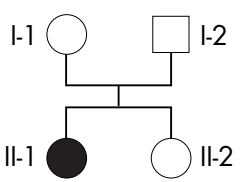

B

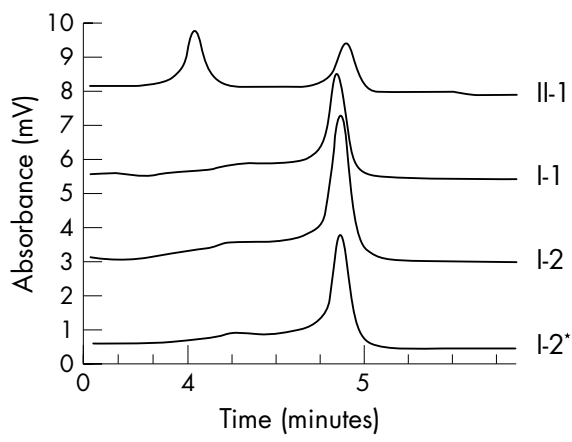

C

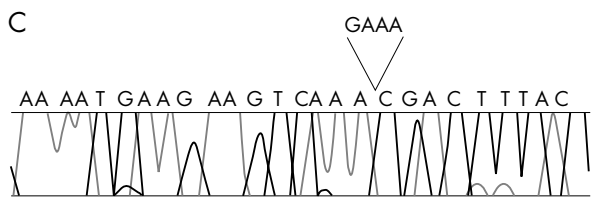

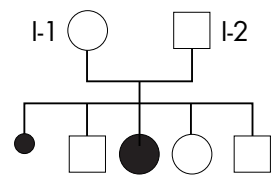

$\begin{array}{lllll}\|-1 & \|-2 & \|-3 & \|-4 & \|-5\end{array}$
Figure 1 Pedigree (A), DHPLC analysis (B), and DNA sequencing (C). Left side, case 1, right side, case 2. (B) An asterisk indicates that the DNA of the father is $1: 1$ mixed with a control male. (C) The chromatograms represent the mutated sequences separated from normal alleles on $6 \%$ polyacrylamide gel. Deleted bases are indicated above.
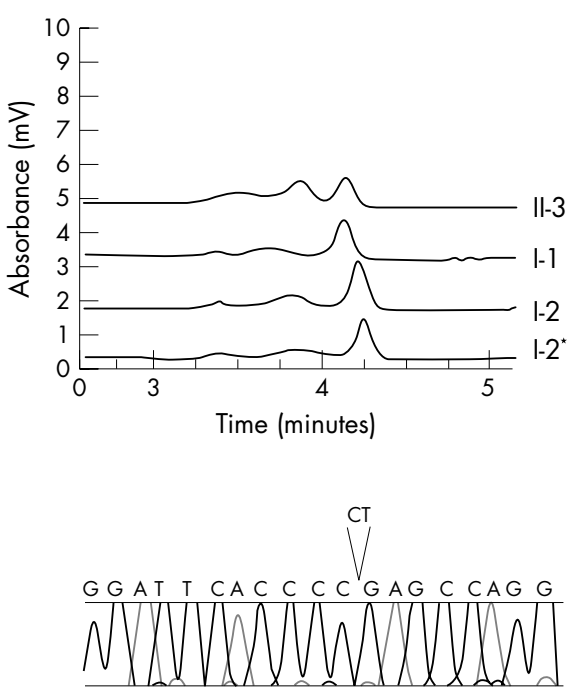

\section{Patient 2}

This patient is a girl, now aged 8 years. Her pedigree is represented in fig lA (right). The mother had a normal pregnancy and delivery, and the child was affected with slight cyanosis at birth. Her birth weight was $3800 \mathrm{~g}$ but no data concerning her head circumference are available. At 10 days, generalised convulsions, lasting only a few seconds, appeared, which were difficult to control with various antiepileptic drugs and persisted during the following years. Myoclonic seizures, when her arms suddenly opened, possibly infantile spasms, were also reported by her parents, although clinical records concerning these details were not available. Her MRI was normal. Her development was delayed; in the first years of life she did not respond to interactions, she had been found hypotonic by medical professionals, and she was unable to hold an object in her hands. She was able to sit alone at 1.5 years of age. She was examined in our unit when 4 years 10 months of age. Her head circumference was $49 \mathrm{~cm}$ (tenth centile), she had a moderate degree of generalised hypotonus, and was unable to hold an object in her hands, which were brought frequently to her mouth and occasionally twisted together. Furthermore, she had myoclonic epileptic fits occurring two or three times a day, and occasional generalised convulsions. An EEG showed generalised discharges of sharp and slow waves and focal sharp waves in the right centrotemporal region. She was evaluated at the age of 7 years 10 months, when a slight improvement in the use of her hands was noted. She could hold a biscuit and some bread in her hands and eat them. Her facial expression varied notably and she was capable of reciprocal modulations. Generalised hypotonus was still present: she was able to sit unaided but unable to walk without support. The stereotypic activities of her hands were still present. She occasionally uttered one or two words. Her head circumference was $50 \mathrm{~cm}$ (tenth centile). Scoliosis, kyphosis, cold extremities, and constipation were absent. Myoclonic fits and generalised convulsions were still present in spite of various treatments, including phenobarbital, valproate, lamotrigine, and carbamazepine. An EEG showed the persistence of generalised sharp and slow waves and the presence of additional multifocal abnormalities.

\section{Molecular analysis}

MECP2 point mutations, including the recently identified exon 1, and gross rearrangements were excluded by DHPLC and quantitative PCR, respectively. ${ }^{20-22}$ Based on the partial clinical overlap between the Hanefeld variant and ISSX, we screened the two RTT variant patients for point mutations in $A R X$ and CDKL5. ARX analysis did not identify any mutation. DHPLC analysis of CDKL5 revealed a different frameshift mutation in the two patients, absent in the DNA of the parents in both cases (fig 1B).

In case 1 we identified a $4 \mathrm{bp}$ deletion in exon 5 (c.163_166delGAAA) (fig 1C; left) leading to loss of most of the CDKL5 protein (NP_003150). The frameshift mutation creates a stop codon in position 74, after a short stretch of abnormal amino acids (fig 2A, 2B; top). This deletion interrupts the catalytic domain covering the first 300 amino acids, and creates a non-functional CDKL 5 product.

Case 2 showed a 2 bp deletion in exon 18 (c.2635 2636delCT) (fig lC; right) leading to protein truncation in position 908, after a short stretch of incorrect amino acids (fig 2A, 2B; bottom). This deletion eliminates a putative signal peptidase I serine active site, as predicted by the ScanProsite program (http://ca.expasy.org/prosite) (fig 2A).

We then investigated whether mutated and normal alleles were expressed in the two patients. We studied $\mathrm{X}$ inactivation in DNA from blood cells of both patients. The assay showed balanced $\mathrm{X}$ inactivation in both cases (not shown). Band intensities were measured: the ratio between the two alleles was 52:48 in case 1 and 67:33 in case 2 . We then performed RT-PCR to test if mutated mRNA alleles were degraded by nonsense mediated RNA decay. RT-PCR products, separated by electrophoresis and silver stained, demonstrated the 


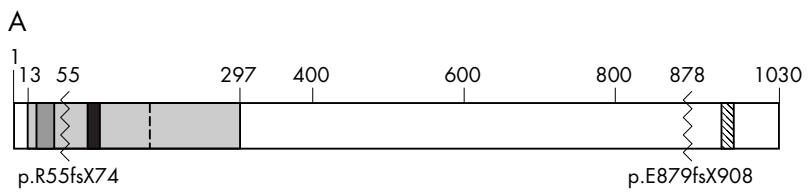

B

CDKL5 normal 49 ENEEVKETTLRELKMLRTLKQENIVELKEAFR 80 CDKL5 mutant 49 ENEEVKRLYESLKCFGLSSRKTLWSX p.E55fs X74

CDKL5 normal 873 EIRIHPLSQASGGSSNIRQEPAPKGRPALQLPDGGCDGRRQR 914 CDKL5 mutant 873 EIRIHP EPGLWREQQHPAGTRTEGQASPPAARRWMX p. 1879 fs $\times 908$

Figure 2 CDKL5 protein with mutation positions (A) and alignment between the normal and the mutated amino acid sequences (B). (A) The catalytic domain (light grey) contains an ATP binding site (dark grey) and the serine-threonine protein kinase active site (dark box). The conserved Thr-Xaa-Tyr motif is indicated with a sketch line. The signal peptidase I serine active site is represented by the reticulated box. The two frameshift deletions are indicated by zigzag lines. The numbers at the top refer to the amino acid positions. (B) In patient 1 (top), the deletion creates a stop codon in position 74. In patient 2 (bottom), the deletion leads to protein truncation in position 908 . Stretches of incorrect amino acids are boxed.

expression of both mutated and normal alleles in the two patients (fig 3 ).

We then extended the CDKL5 analysis to 19 classic RTT and 15 PSV cases, all MECP2 negative; no mutation was found.

\section{DISCUSSION}

The two girls reported above had a similar clinical course: they showed convulsions very early in life, respectively at 1.5 months and at 10 days, drug resistant in both cases. They otherwise fulfilled the criteria for RTT, including acquired microcephaly, hand apraxia, generalised hypotonus, and stereotypic hand activities. ${ }^{45}{ }^{16}$ Hyperventilation was present in one girl. Scoliosis, constipation, and cold feet were absent in both, suggesting a possibly better preserved autonomic system. It was difficult to retrospectively assess whether they had had the typical stage sequence of RTT. When examined at ages close to 8 and 5 years, they were expressive and interacted in a manner adequate to their reduced general abilities, and they fulfilled the criteria for the early seizure variant of RTT. ${ }^{5}{ }^{16}$ It should be noted that only a few cases of this disorder have been reported ${ }^{4}$ and, with the exception of the first case described by Hanefeld (personal communication), no MECP2 mutations have been described. In the two

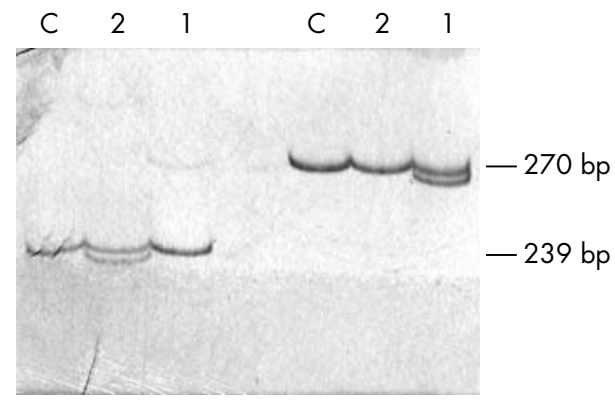

Figure 3 RT-PCR analysis of patients (1 and 2) and a control individual (C). The polyacrylamide gel shows RT-PCR products. RT-PCR products spanning exons 17-18 (left) and exons 4-6 (right). In both cases, the mutant allele is evident as a lower band. Size is indicated on the right.
RTT variant patients, MECP2 point mutations and gross rearrangements were excluded by DHPLC and qPCR.

Our results indicate that RTT variant with infantile spasms may be due to inactivating CDKL5 mutations. CDKL5 is a member of the serine-threonine kinase gene family. ${ }^{23}$ Kinase proteins are a large superfamily of homologous proteins, characterised by a highly conserved kinase domain (250-300 amino acids). The CDKL5 kinase domain is most closely related to human KKIALRE and KKIAMRE and their orthologues. ${ }^{23}$ The sequence alignment of the CDKL5 protein with these homologues showed two kinase signatures in the catalytic domain: an ATP binding region (amino acids 14 to 47 ) and a serine-threonine protein kinase active site (amino acids 127 to 144). ${ }^{23}$ In addition, a Thr-Xaa-Tyr motif was identified, ${ }^{23}$ and the dual phosphorylation of these Thr and Tyr residues has been shown to be essential for activation of the MAP kinase group. ${ }^{24}$

The frameshift mutation found in patient 1 is located in the conserved kinase domain of the CDKL5 protein, causing loss of both the serine threonine active site and the Thr-XaaTyr motif. Thus, the deletion abolishes the catalytic function of the protein. Furthermore, it has been reported that lack of functional CDKL5 protein causes severe ISSX. ${ }^{15}$ This finding was derived from a study of two severely affected ISSX female patients with apparently de novo balanced $\mathrm{X}$; autosome translocations, both disrupting the CDKL5 gene in the kinase domain. Additional studies are needed to further elucidate why different truncating mutations in CDKL5 cause different but overlapping phenotypes.

Except for the kinase domain, the function of the CDKL5 protein is unknown (fig $2 \mathrm{~A}$ ). The region between positions 300 and 1030 is not conserved in different species and does not share a homology with other human proteins, making it difficult to predict its function. ${ }^{25}$ The deletion found in case 2 falls in the $\mathrm{C}$ terminus of the protein. We could speculate that this region contains a functional domain specific for human CDKL5. Using the ScanProsite program we identified a signal peptidase I serine active site (GTSMCPTL), located between positions 971 and 978, abolished by the deletion in patient 2 . This domain is one of the five conserved domains present in all known signal peptidases. ${ }^{26}$ CDKL5 probably does not have a peptidase activity, as it lacks other conserved residues necessary for the catalytic activity. ${ }^{26}{ }^{27}$ However, we cannot exclude that CDKL5 might form a complex with other proteins that harbour the other essential domains.

A C terminal deletion of CDKL5 has already been reported by Huopaniemi et $a^{28}$ in a family with $\mathrm{X}$ linked juvenile retinoschisis (RS). No additional phenotype was reported in these patients with the exception of epilepsy in one. This deletion, spanning from the $5^{\prime}$ region of the RS1 gene to intron 3, disrupts two other genes, PPEF-1 and CDKL5 (exon $20)$. It is possible that this truncation, more $3^{\prime}$ than that reported here, generates a milder phenotype.

Finally, it is important to understand why MECP2 and CDKL5 mutations lead to a similar phenotype. MeCP2 and CDKL5 could belong to the same signalling pathway. As it has demonstrated that MeCP2 is subjected to phosphorylation and that CDKL5 has a kinase domain, it is possible that MeCP2 is directly phosphorylated by CDKL5. ${ }^{23}{ }^{29}$ However, at least in patient 1 , CDKL5 kinase activity is abolished, and a reduced degree of MeCP2 phosphorylation would lead to a reduction in its dissociation from methylated DNA and to a gene silencing increase. ${ }^{29}$ However, is known that MECP2 mutations presumably cause a reduction of gene silencing..$^{30}$ Alternatively, CDKL5 might phosphorylate a second protein that could dephosphorylate MeCP2. Additional studies are necessary to determine whether MeCP2-CDKL5 interaction really exists and to unravel the complex mechanisms underlying the above phenotypes. 


\section{ACKNOWLEDGEMENTS}

This study was supported by Telethon grants GGP02372A and GTF02006, by the Emma and Ernesto Rulfo Foundation, by the Ministry of Health (Progetti di Ricerca Finalizzata, D.L. 502/92-2003), by MIUR (FIRB 01), and by the University of Siena (PAR 2001 and PAR 2002) to A Renieri. We thank F Hanefeld for a critical reading of the manuscript.

\section{Authors' affiliations}

E Scala, F Ariani, F Mari, R Caselli, C Pescucci, I Longo, I Meloni,

D Giachino, M Bruttini, A Renieri, Medical Genetics, Departement of Molecular Biology, University of Siena

G Hayek, M Zappella, Child Neuropsychiatry, University of Siena

Competing interests: none declared

The first two authors contributed equally to this work

\section{REFERENCES}

1 Zappella M. The Rett girls with preserved speech. Brain Dev 1992; 14:98-101.

2 Goutieres F, Aicardi J. Atypical forms of Rett syndrome. Am J Med Genet Suppl 1986;1:183-94.

3 Hanefeld F. The clinical pattern of the Rett syndrome. Brain Dev 1985;7:320-25.

4 Hagberg BA, ed. Rett syndrome-clinical \& biological aspects. London: McKeith Press, 1993.

5 Hagberg BA, Skjeldal $\mathrm{OH}$. Rett variants: a suggested model for inclusion criteria. Pediatr Neurol 1994;11:5-11.

6 Hagberg B, Rasmussen P. "Forme frustes" of Rett syndrome-a case report Am J Med Genet 1986;24(suppl 1):175-81.

7 Amir RE, Van den Veyver IB, Wan M, Tran CQ, Francke U, Zoghbi HY. Rett syndrome is caused by mutations in X-linked MECP2, encoding methyl-CpGbinding protein 2. Nat Genet 1999;23:185-8

8 Miltenberger-Miltenyi G, Laccone F. Mutations and polymorphisms in the human methyl CpG-binding protein MECP2. Hum Mutat 2003;22:107-15.

9 Renieri A, Meloni I, Longo I, Ariani F, Mari F, Pescucci C, Cambi F. Rett syndrome: the complex nature of a monogenic disease. $J$ Mol Med 2003;81:346-54.

10 De Bona C, Zappella M, Hayek G, Meloni I, Vitelli F, Bruttini M, Cusano R, Loffredo $P$, Longo I, Renieri A. Preserved speech variant is allelic of classic Rett syndrome. Eur J Hum Genet 2000;8:325-30.

11 Yamashita Y, Kondo I, Fukuda T, Morishima R, Kusaga A, Iwanaga R, Matsuishi T. Mutation analysis of the methyl-CpG-binding protein 2 gene (MECP2) in Rett patients with preserved speech. Brain Dev 2001;23(suppl 1):S157-60.

12 Zappella M, Meloni I, Longo I, Canitano R, Hayek G, Rosaia L, Mari F, Renieri A. Study of MECP2 gene in Rett syndrome variants and autistic girls. Am J Med Genet (Neuropsychiatr Genet) 2003;119B:102-7.

13 Bienvenu $T$, Poirier K, Friocourt $G$, Bahi $N$, Beaumont $D$, Fauchereau $F$, Ben Jeema L, Zemni R, Vinet MC, Francis F, Couvert $P$, Gomot $M$, Moraine $C$, van Bokhoven H, Kalscheuer V, Frints S, Gecz J, Ohzaki K, Chaabouni H, Fryns JP, Desportes V, Beldjord C, Chelly J. ARX, a novel Prd-class-homeobox gene highly expressed in the telencephalon, is mutated in X-linked mental retardation. Hum Mol Genet 2002;11:981-91.

14 Stromme P, Mangelsdorf ME, Shaw MA, Lower KM, Lewis SM, Bruyere H, Lutcherath V, Gedeon AK, Wallace RH, Scheffer IE, Turner G, Partington M, Frints SG, Fryns JP, Sutherland GR, Mulley JC, Gecz J. Mutations in the human ortholog of Aristaless cause X-linked mental retardation and epilepsy. Nat Genet 2002;30:441-5.

15 Kalscheuer VM, Tao J, Donnelly A, Hollway G, Schwinger E, Kubart S, Menzel C, Hoeltzenbein M. Tommerup N, Eyre H, Harbord M, Haan E, Sutherland GR, Ropers HH, Gecz J. Disruption of the serine/threonine kinase 9 gene causes severe $X$-linked infantile spasms and mental retardation. Am J Hum Genet 2003;72:1401-11.

16 Hagberg B, Goutieres F, Hanefeld F, Rett A, Wilson J. Rett syndrome: criteria for inclusion and exclusion. Brain Dev 1985:7:372-3.

17 Trevathan E, Moser HW. Diagnostic criteria for Rett syndrome. Ann Neurol 1988;23:425-8.

18 Pegoraro E, Schimke RN, Arahata K, Hayashi Y, Stern H, Marks H, Glasberg MR, Carroll JE, Taber JW, Wessel HB. Detection of new paternal dystrophin gene mutations in isolated cases of dystrophinopathy in females. Am J Hum Genet 1994;54:989-1003.

19 Sambrook J, Fritsch EF, Maniatis T. Molecular cloning: a laboratory manual, 2nd ed. Cold Spring Harbor: Cold Spring Harbor Laboratory Press, 1989.

20 Kriaucionis SAB. The major form of $\mathrm{MeCP} 2$ has a novel $\mathrm{N}$-terminus generated by alternative splicing. Nucleic Acids Res 2004;32:1818-23.

21 Ariani F, Mari F, Pescucci C, Longo I, Bruttini M, Meloni I, Hayek G, Rocchi R, Zappella M, Renieri A. Real-time quantitative PCR as a routine method for screening large rearrangements in Rett syndrome: Report of one case of MECP2 deletion and one case of MECP2 duplication. Hum Mutat 2004;24:172-7.

22 Buyse IM, Fang P, Hoon KT, Amir RE, Zoghbi HY, Roa BB. Diagnostic testing for Rett syndrome by DHPLC and direct sequencing analysis of the MECP2 gene: identification of several novel mutations and polymorphisms. Am J Hum Genet 2000;67:1428-36

23 Montini E, Andolfi G, Caruso A, Buchner G, Walpole SM, Mariani M, Consalez G, Trump D, Ballabio A, Franco B. Identification and characterization of a novel erine-threonine kinase gene from the $\mathrm{Xp22}$ region. Genomics 1998:51:427-33.

24 Hanks SK, Hunter T. Protein kinases 6. The eukaryotic protein kinase superfamily: kinase (catalytic) domain structure and classification. FASEB J 1995;9:576-96.

25 Brunner B, Todt T, Lenzner S, Stout K, Schulz U, Ropers HH, Kalscheuer VM. Genomic structure and comparative analysis of nine Fugu genes: conservation of synteny with human chromosome Xp22.2-p22.1. Genome Res 1999;9:437-48.

26 Dalbey RE, Lively MO, Bron S, van Dij JM. The chemistry and enzymology of the type I signal peptidases. Protein Sci 1997:6:1129-38.

27 Tjalsma H, Stover AG, Driks A, Venema G, Bron S, van Dijl JM. Conserved serine and histidine residues are critical for activity of the ER-type signal peptidase SipW of Bacillus subtilis. J Biol Chem 2000;275:25102-8.

28 Huopaniemi L, Tyynismaa H, Rantala A, Rosenberg T, Alitalo T. Characterization of two unusual RS1 gene deletions segregating in Danish retinoschisis families. Hum Mutat 2000; 16:307-14.

29 Chen WG, Chang Q, Lin Y, Meissner A, West AE, Griffith EC, Jaenisch R, Greenberg ME. Derepression of BDNF transcription involves calciumdependent phosphorylation of MeCP2. Science 2003;302:885-9.

30 Shahbazian M, Zoghbi H. Rett Syndrome and MeCP2: Linking epigenetics and neuronal function. Am J Hum Genet 2002;71:1259-72. 